\title{
Effect of Anion on the C-Cl Bond Cleavage of Toxic Organochlorides Electrocatalyzed by Co(II) Porphyrin
}

\author{
Yuanyuan Qiu, He Luo, Minzhi Li, Junxia Wen, Weihua Zhu, ${ }^{@ 1}$ Xifeng Zhang, \\ and $\mathrm{Xu}$ Liang ${ }^{\circledR 2}$ \\ School of Chemistry and Chemical Engineering, Jiangsu University, 212013 Zhenjiang, China \\ ${ }^{\circledR 1}$ Corresponding authorE-mail: sayman@ujs.edu.cn \\ ${ }^{@ 2}$ Corresponding author E-mail: liangxu@ujs.edu.cn
}

\begin{abstract}
An electrochemically reduced Co(I) meso-tetraphenylporphyrin anion was examined in electron reductive dechlorination of environmental harmful organochlorides by using various supporting electrolytes. The tunable reactivities were formed when different supporting electrolytes were tested. For the first time the experimental and mechanistic investigations were combined, what provided useful information for future rational molecular design towards highly efficient removal of environmental harmful organochloride catalyzed by metalloporphyrins.
\end{abstract}

Keywords: $\mathrm{C}-\mathrm{Cl}$ bond cleavage, toxic organochloride, anion effect, metalloporphyrin, electrocatalysis.

\section{Влияние аниона на расщепление связи $\mathrm{C}-\mathrm{Cl}$ токсичных органохлоридов, катализируемое Со(II) порфирином}

\author{
Ю. Киу, Х. Ауо, М. Аи, Ю. Вен, В. Жу, ${ }^{\circledR 1}$ К. Жанг, К. Аианг ${ }^{\circledR 2}$ \\ Школа химии и химической инженерии, Университет Цзянсу, 212013 Чжэньизян, Китай \\ ${ }^{\circledR 1}$ E-mail: sayman@ujs.edu.cn \\ ${ }^{@ 2}$ E-mail: liangxu@ujs.edu.cn
}

\begin{abstract}
Анион Со(I) мезо-тетрафенилпорфирина, полученный электрохимическим восстановлением, исследовали в качестве потенциального агента дехлорирования экологически вредных органических соединений в среде различных электролитов. Комбинация экспериментальных и механистических исследований позволила получить важную информацию для молекулярного дизайна детоксикантов на основе каталитически активных металлопорфиринов.
\end{abstract}

Ключевые слова: Расщепление связи C-Cl, токсичный органохлорид, анион-эффект, металлопорфирин, электрокатализ.

\section{Introduction}

Organochlorides have been widely used as agricultural insecticides and in pharmaceutical treatments for lice and scabies. ${ }^{[1-3]}$ Unfortunately, even low concentrations of organochlorides, such as lindane $(\gamma-\mathrm{HCH}), \alpha-\mathrm{HCH}$, DDT, and merix, can pose a considerable threat to human health and the ecosystem, since they tend to be quite easily accumulated in lipid-rich tissues of biota and biomagnified through terrestrial and aquatic food chains. ${ }^{[4-6]}$ In addition, most organochlorides are degraded very slowly in the environment, but several disposal and remediation techniques have been fully developed to effectively achieve the degradation of these compounds. At present, the degradation of environmentally toxic organochlorides can be partially or fully achieved by using non-metallic and metallic nano-catalysts ${ }^{[7-10]}$ through carbon-chloride bond cleavage reactions. Also, naturally occurring vitamin $\mathrm{B}_{12}$ can also 
catalyze the activation reaction of the carbon-halogen bonds in the presence or absence of other enzymes. ${ }^{[1-15]}$ Based on the similar structure with vitamin $B_{12}$, metalloporphyrinoids can also be used as efficient catalysts for the $\mathrm{C}-\mathrm{Cl}$ bond cleavage of environmentally harmful organochloride through an electrocatalytic reduction process. ${ }^{[16-21]}$ An in-depth study of the mechanism has demonstrated that the first step is a dissociative electron transfer from the reduced metal-center to the organochloride, leading to chloride elimination and the formation of a radical species. The re-oxidized metal complexes can then be re-used for the next catalytic cycle. Unfortunately, study on the chemical environment of electrochemically catalyzed $\mathrm{C}-\mathrm{Cl}$ bond cleavage have less considered previously, such as anion effect. In this study, the detailed experimental and mechanistic characterizations of electrocatalyzed $\mathrm{C}-\mathrm{Cl}$ bond cleavage of environmentally toxic organochlorides will be described.

\section{Experimental}

All reagents and solvents for electrochemical measurements were of commercial spectral pure reagent grade purchased from Alading Company (China) and were used without further purification except where noted. Other chemicals for organic synthesis are all analytical pure grade and used directly. Cyclic voltammetry measurements were carried out in a three-electrode cell using a Chi-730D electrochemistry station. A glassy carbon disk electrode was used as the working electrode, and the counter and reference electrodes were platinum mesh and a saturated calomel electrode (SCE), respectively. An " $\mathrm{H}$ " type cell with a fritted glass layer to separate the cathodic and anodic sections of the cell was used for bulk electrolysis. Both the working and reference electrodes were placed in one compartment while the counter electrode was in the other cell compartment. A pre-treatment procedure was required prior to the GC-MS measurements to remove the supporting electrolyte (TBAP, TBAC, TBAB). The DMF solvent was evaporated under vacuum at $45^{\circ} \mathrm{C}$ on a rotary evaporator. Cyclohexane was then added to extract DDT and the dechlorinated products from the residue. The TBAP was removed after stirring and centrifuging, prior to the GC-MS analysis on HP6890-GC and HP5975-MSD systems with an HP-5 $5 \%$ phenyl methyl siloxane column (length $30 \mathrm{~m}$, ID $250 \mu \mathrm{m}$, film $0.25 \mu \mathrm{m}$ ). The temperature was initially set at $100{ }^{\circ} \mathrm{C}$ and was then programmed to rise at $15{ }^{\circ} \mathrm{C} / \mathrm{min}$ until a maximum of $300^{\circ} \mathrm{C}$ was reached. The molar response factors of some of the intermediate products could not be determined, since the appropriate reagent is not commercially available.

\section{Results and Discussion}

\section{Electrochemistry}

During the electrochemistry measurements, a significant increase is observed in the reduction peak current for Co(II) porphyrin 1 (Chart 1) upon addition of 0.0-2.0 eq lindane while the reverse anodic peak for the re-oxidation part either decreases or disappears in DMF solution containing $0.1 \mathrm{M}\left[n \mathrm{Bu}_{4} \mathrm{~N}\right] \mathrm{ClO}_{4}$ (TBAP), $\left[n \mathrm{Bu}_{4} \mathrm{~N}\right] \mathrm{Br}$ (TBAB), $\left[n \mathrm{Bu}_{4} \mathrm{~N}\right] \mathrm{Cl}$ (TBAC), respectively. As shown in Figure 1, the redox couples at $c a$. $E=-0.7$ to $-0.8 \mathrm{~V}$ can be assigned to the $\mathrm{Co}^{\mathrm{II}} / \mathrm{Co}^{\mathrm{I}}$ couple of $\mathrm{Co}(\mathrm{II})$ meso-tetraphenylporphyrin, these interesting $\mathrm{CV}$ properties are in consistent with a catalytic process involving lindane and the electrogenerated $\mathrm{Co}(\mathrm{I})$ porphyrin to yield a $\sigma$-bonded $\mathrm{Co}(\mathrm{III})$ derivative. Additional irreversible reduction peaks can be assigned to the reduction of one or more $\sigma$-bonded Co(III) porphyrin, which are generated from the reaction of $\left[(\text { Por }) \mathrm{Co}^{\mathrm{I}}\right]^{-}$anion and toxic organochlorides. The comparison between the reduction peak current with different amount of lindane $\left(i_{\mathrm{p}}\right)$ and without DDT $\left(i_{\mathrm{p} 0}\right), i_{\mathrm{p}} / i_{\mathrm{p} 0}$ values clearly reveal the different electrochemical response in these three oxidation/reduction processes shown in Figure 2. It has been clearly shown that the higher intensity was observed when TBAB was used as the supporting electrolyte. Similarly, when DDT and $\alpha-\mathrm{HCH}$ were tested as the comparing toxic

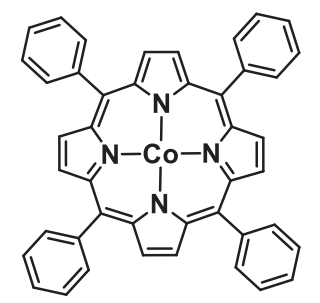

Chart 1. Molecular structure of Co(II) meso-tetraphenylporphyrin 1. (a)

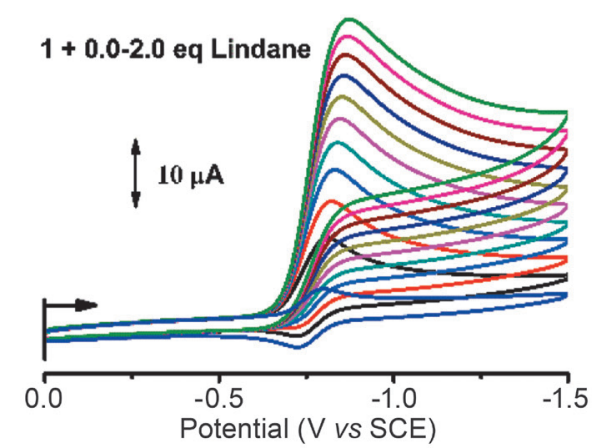

(b)

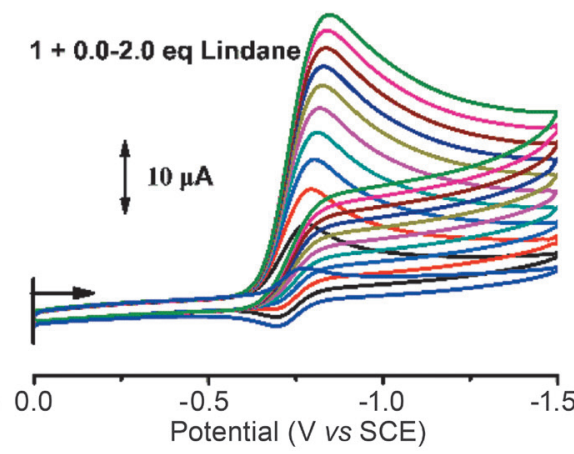

(c)

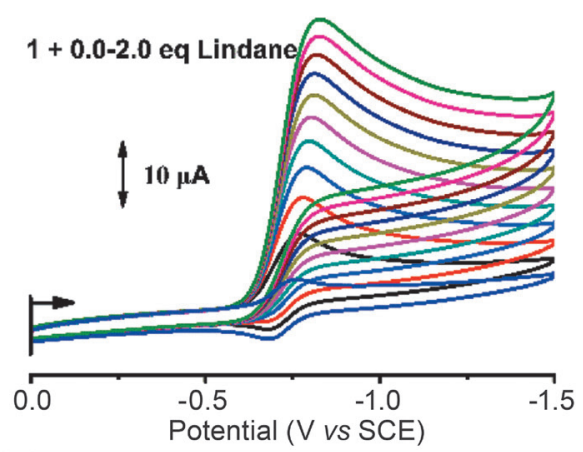

Figure 1. Reductive electrochemistry of Co(II) porphyrin 1 in DMF containing $0.1 \mathrm{M}$ (a) TBAB, (b) TBAP and (c) TBAC upon addition of $0.0-2.0$ eq lindane. 
organochlorides, the electrochemical responses were also observed (Figure 2). Since the electrochemical response of Co(II) porphyrin was stronger in the presence of lindane compared with other organochlorides, and further electrochemical characterizations were focused on the lindane in various supporting electrolytes. The surface electrochemical behaviors were determined from $\mathrm{CV}$ measurements for 1 in the presence of 0.1 eq lindane made at various scan-rates from $20-500 \mathrm{mV}$ (Figure 3 ) to provide an insight into the reversibility of the system on an experimental timescale. The good linear correlations observed for plots of peak current $v s . v^{1 / 2}$ for 1 in the presence of 0.1 eq lindane (Fig- ure 4) confirm that all oxidation and reduction processes are diffusion controlled.

\section{Electrocatalyzed C-Cl bond Cleavage and Plausible Mechanism}

Since reductive catalytic behavior is more effective and lindane was selected as the example to study the anion effect of supporting electrolyte on the electrocatalyzed high-efficient and recycable carbon-chloride bond cleavage, the $\mathrm{C}-\mathrm{Cl}$ bond cleavage products and reaction kinetics of the controlled-potential bulk electrolysis were analyzed
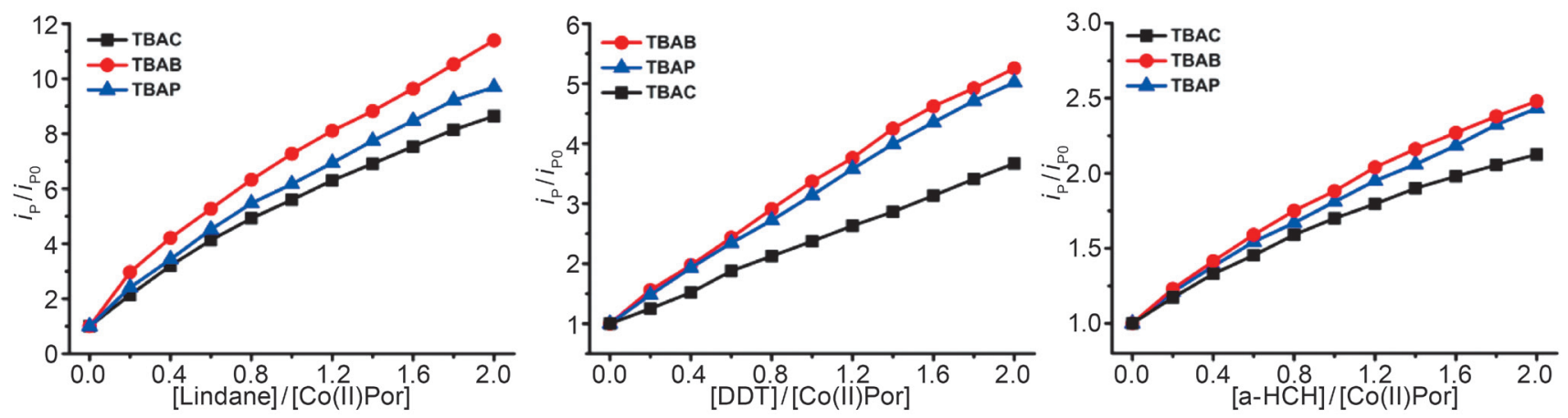

Figure 2. Dependence plot of catalytic peak $(i \mathrm{p})$ /original peak $\left(i_{\mathrm{p} 0}\right)$ ration on reductive electrochemistry of Co(II)Por 1 in DMF containing 0.1 M TBAB, TBAP and TBAC upon addition of $0.0-2.0$ eq lindane (left), DDT (middle) and $\alpha-\mathrm{HCH}$ (right).
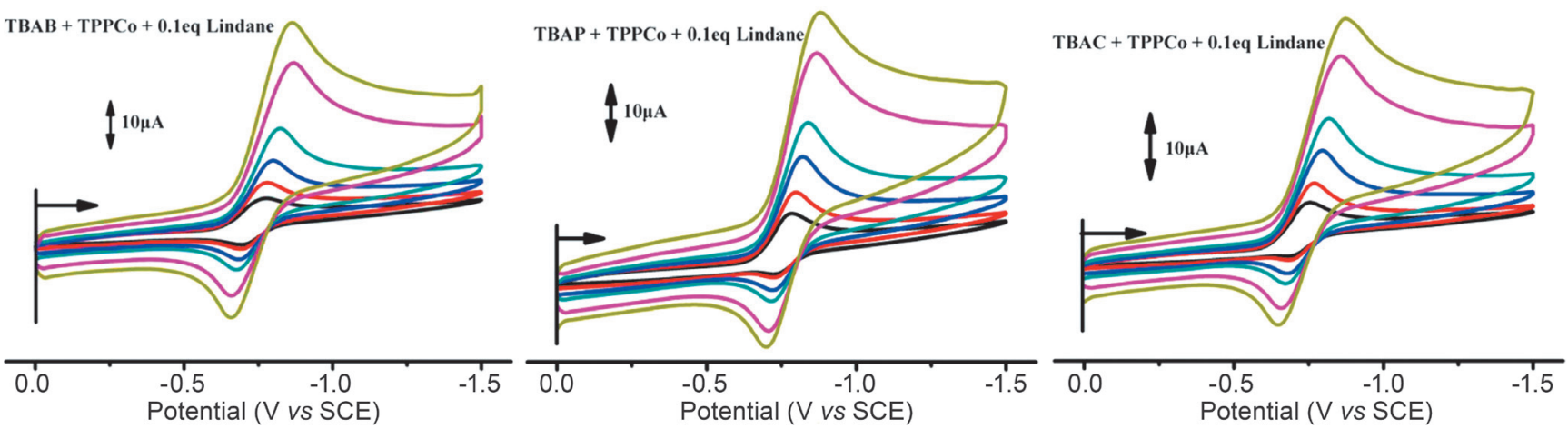

Figure 3. Electrochemical measurements for the reduction of $\mathrm{Co}(\mathrm{II})$ porphyrin 1 in the presence of 0.1 eq lindane in DMF containing 0.1 M TBAB (left), TBAP (middle) and TBAC (right) at different scan rates of 10, 20, 50, 100, 300 and $500 \mathrm{mV} / \mathrm{s}$.
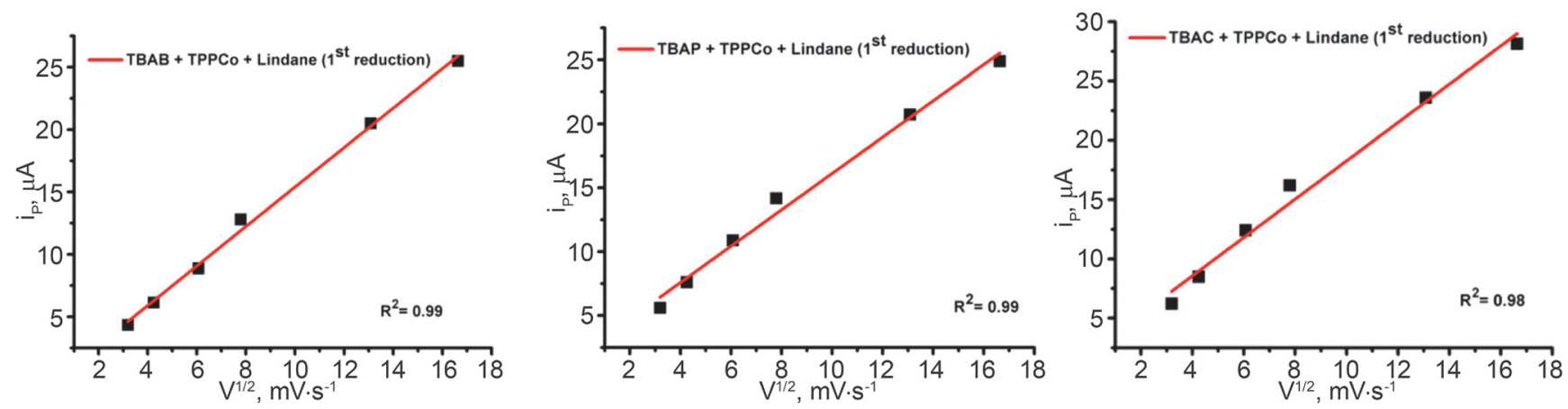

Figure 4. The dependence of square root of the scan-rate $\left(\mathrm{v}^{1 / 2}\right)$ on the peak current $\left(i_{\mathrm{p}}\right)$ for the 1st reduction steps during cyclic voltammetry measurements of $\mathbf{1}$ in the presence of 0.1 eq lindane containing $0.1 \mathrm{M}$ TBAB, TBAP and TBAC. 
Table 1. Time-dependent distribution of carbon-chloride bond cleavage of 1 in the presence of 10.0 eq lindane in DMF containing $0.1 \mathrm{M} \mathrm{TBAB}$.

\begin{tabular}{ccccc}
\hline \multirow{2}{*}{ Time, h } & \multicolumn{4}{c}{ Products, \% } \\
\cline { 2 - 5 } & Lindane & TCB & DCB & CB \\
\hline 0.0 & 100 & 0 & 0 & 0 \\
0.2 & 10.59 & 26.03 & 15.50 & 23.41 \\
0.5 & 6.70 & 26.35 & 19.26 & 24.80 \\
1.0 & 3.65 & 31.04 & 23.04 & 23.31 \\
2.0 & 1.88 & 30.06 & 32.51 & 21.81 \\
3.0 & 0.47 & 26.95 & 40.02 & 16.46 \\
4.0 & 0 & 24.01 & 49.74 & 15.39 \\
5.0 & 0 & 23.10 & 55.03 & 11.59 \\
\hline
\end{tabular}

Table 2. Time-dependent distribution of carbon-chloride bond cleavage of 1 in the presence of 10.0 eq lindane in DMF containing 0.1 M TBAP.

\begin{tabular}{ccccc}
\hline \multirow{2}{*}{ Time, h } & \multicolumn{4}{c}{ Products, \% } \\
\cline { 2 - 5 } & Lindane & TCB & DCB & CB \\
\hline 0.0 & 100 & 0 & 0 & 0 \\
0.2 & 19.96 & 27.71 & 28.33 & 6.67 \\
0.5 & 6.48 & 22.81 & 29.90 & 15.64 \\
1.0 & 2.41 & 21.83 & 31.03 & 24.70 \\
2.0 & 0.65 & 17.57 & 30.65 & 36.73 \\
3.0 & 0 & 13.30 & 24.29 & 48.14 \\
4.0 & 0 & 12.07 & 24.24 & 53.88 \\
5.0 & 0 & 11.65 & 21.14 & 47.34 \\
\hline
\end{tabular}

Table 3. Time-dependent distribution of carbon-chloride bond cleavage of 1 in the presence of 10.0 eq lindane in DMF containing $0.1 \mathrm{M}$ TBAC.

\begin{tabular}{ccccc}
\hline \multirow{2}{*}{ Time, h } & \multicolumn{4}{c}{ Products, \% } \\
\cline { 2 - 5 } & Lindane & TCB & DCB & CB \\
\hline 0.0 & 100 & 0 & 0 & 0 \\
0.2 & 27.30 & 17.27 & 24.77 & 7.74 \\
0.5 & 17.61 & 19.26 & 31.01 & 12.03 \\
1.0 & 16.06 & 20.52 & 30.99 & 15.48 \\
2.0 & 11.71 & 19.73 & 33.28 & 19.21 \\
3.0 & 6.81 & 18.53 & 32.87 & 24.69 \\
4.0 & 3.67 & 16.44 & 29.84 & 32.16 \\
5.0 & 0 & 11.64 & 25.74 & 52.07 \\
\hline
\end{tabular}

using $15 \mathrm{~mL}$ of a $1.0 \cdot 10^{-3} \mathrm{M}$ lindane and $0.5 \cdot 10^{-4} \mathrm{M} \mathrm{Co}(\mathrm{II})$ porphyrin solution in DMF. The applied potential was set at $E=-1.60 \mathrm{~V}$, which was sufficiently negative to generate the $[\mathrm{Co}(\mathrm{I}) \text { porphyrin] }]^{-}$species, to reduce any homogeneously generated $\sigma$-bonded $\mathrm{Co}(\mathrm{II})$ porphyrin products, and the environmentally toxic organochlorides were not be dechlorinated under current electrochemical conditions by themselves. A

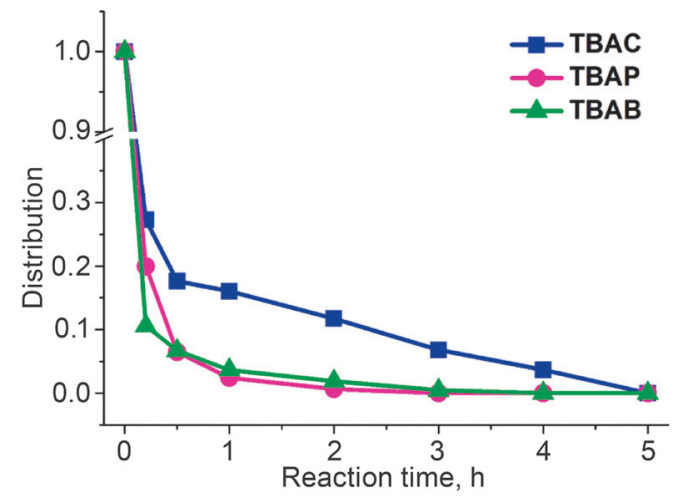

Figure 5. Time-dependent distribution of GC-MS analysis of $\mathbf{1}$ in the presence of 10.0 eq lindane in DMF containing $0.1 \mathrm{M}$ TBAB, TBAP and TBAC.

time-dependent GC-MS analysis of the $\mathrm{C}-\mathrm{Cl}$ bond cleavage products observed after 1 to 5 hours of electrolysis was carried out. As seen from Tables 1-3 and Figure 5, 10.0 eq lindane are completely removed from the solution within $5 \mathrm{~h}$ after starting bulk electrolysis at an applied potential of $E=-1.70 \mathrm{~V}$. When $\left[n \mathrm{Bu}_{4} \mathrm{~N} \mathrm{ClO}_{4}\right.$ (TBAP) was used as the supporting electrolyte, lindane was firstly converted to trichlorobenzene and its geometric isomers (TCBs), and the further $\mathrm{C}-\mathrm{Cl}$ bond cleavages were also observed to give dichlorobenzen and chlorobenzene. In addition, the $\mathrm{C}-\mathrm{Cl}$ bond cleavage efficiency was significantly decreased when $\left[n \mathrm{Bu}_{4} \mathrm{~N}\right] \mathrm{Cl}$ (TBAC) was used instead, and this could explained as the higher $\left[\mathrm{Cl}^{-}\right]$concentration would change the electrochemically catalyzed reaction equilibrium to yield the lower converting speed. On the other hand, the reaction speed was increased again when $\left[n \mathrm{Bu}_{4} \mathrm{~N}\right] \mathrm{Br}$ (TBAB) was used as the supporting electrolyte and efficient $\mathrm{C}-\mathrm{Cl}$ bond cleavage of chlorobenzene (CB) was also observed according to the time-dependent GC-MS analysis.

In previous study, ${ }^{[20-21]}$ in situ UV-visible spectroelectrochemistry was utilized to monitor the products of a chemical reaction involving organochlorides and electrogenerated metalloporphyrins anions. Spectroelectrochemistry is also used in the current study to monitor the reductions of $\mathrm{Co}(\mathrm{I})$ porphyrin in DMF in the presence of $\mathrm{HCH}$. Examples of the spectral changes which occur during the first two reductions of [Co(I)Por] anion in the presence of lindane containing different supporting electrolytes are shown in Figure 6. Identical spectral changes are observed during the first one-electron reduction of cobalt porphyrin in DMF with added 10.0 eq lindane (Figure 6). However, the current spectral changes were significantly changed from cobalt porphyrin itself in the same solution. This result confirms that $\mathrm{Co}(\mathrm{I})$ porphyrin highly react with lindane under the given solution conditions. In this case, the final UV-visible spectrum displays a singly intense Soret band at $440 \mathrm{~nm}$ (Figure 6). The spectroelectrochemical data in Figure 6 are thus consistent with the cyclic voltammetric data in Figures 1-2 in that a catalytic reaction involving organochlorides and the electrogenerated $\mathrm{Co}(\mathrm{I})$ porphyrin anion occurs after the second reduction in DMF containing added various environmentally toxic organochlorides. 


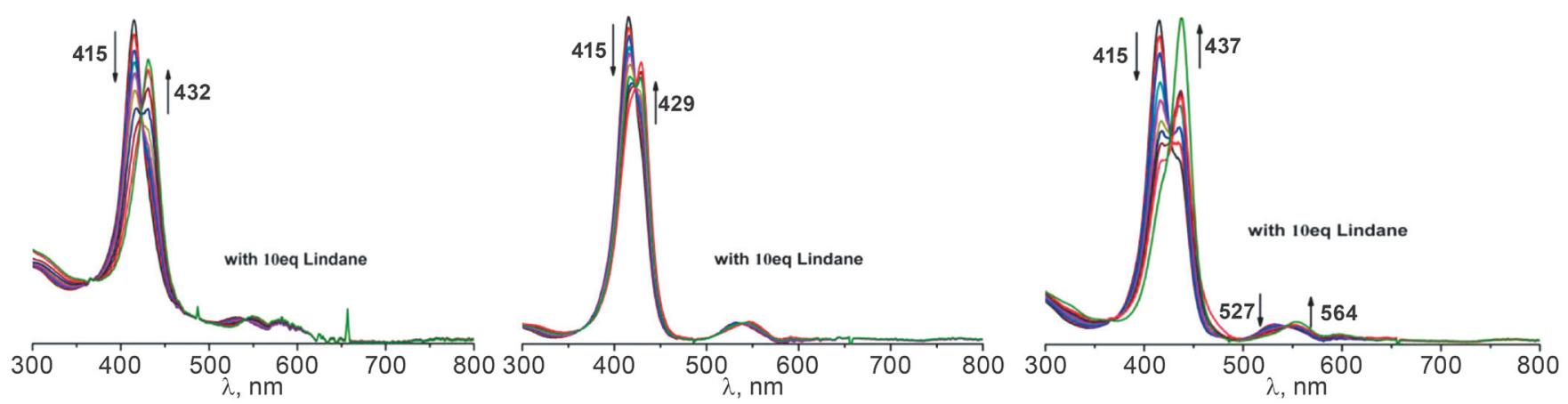

Figure 6. Reductive spectroelectrochemical characterization of Co(II) porphyrin $\mathbf{1}$ in the presence of 10.0 eq of lindane in DMF containing $0.1 \mathrm{M}$ TBAB (left), TBAP (middle) and TBAC (right) at $E=-0.78 \mathrm{~V}$.

\section{Conclusions}

A synthetic $\mathrm{Co}$ (II) meso-tetraphenylporphyrin was examined in electron reductive dechlorination of environmental harmful lindane in nonaqueous media by using various supporting electrolytes. Electrochemical and spectroelectrochemical characterizations were carried out to experimentally and theoretically confirm the effect of anion on the electroreductive catalyzed $\mathrm{C}-\mathrm{Cl}$ bond cleavage of environmentally toxic organochlorides. The time dependent GC-MS analysis exhibits $100 \%$ overall degradation efficiency of lindane by using the controlled potential electrolysis, and the reactivity was arranged in an order of TBAB $>$ TBAP $>$ TBAC. Considering electrocatalyzed $\mathrm{C}-\mathrm{Cl}$ bond cleavage has a wide range of applications in various fields, this study provides useful information for future rational molecular design towards highly efficient removal of environmental harmful organochloride catalyzed by metalloporphyrins.

Acknowledgements. Financial support was provided by the National Scientific Foundation of China (No. 21701058), the National Scientific Foundation of Jiangsu Province (No. BK20160499), the fund from the State Key Laboratory of Coordination Chemistry (No. SKLCC1710, SKLCC1815) and the fund from the Key Laboratory of Functional Inorganic Material Chemistry (Heilongjiang University) of Ministry of Education.

\section{References}

1. Zhang L., Ma J., Venkatesh S., Li Y., Cheung P. Environ. Sci. Technol. 2008, 42, 8791-8797.
2. Arkas M., Allabashi R., Tsiourvas D., Mattausch E.M., Perfler R. Environ. Sci. Technol. 2006, 40, 2771-2777.

3. Marin M.L., Santos-Juanes L., Arques A., Amat A.M., Miranda M.A. Chem. Rev. 2012, 112, 1710-1750.

4. Beard J. J. Sci. Total Environ. 2006, 355, 78-89.

5. Rogan W.J., Chen A.M. Lancet 2005, 266, 763-773.

6. Sharma V.P. Curr. Sci. 2003, 85, 1532-1537.

7. Gupta S.S., Chakraborty I., Maliyekkal S.M., Mark T.A., Pandey D.K., Das S.K., Pradeep T. ACS Sustainable Chem. Eng. 2015, 3, 1155-1163.

8. Ukisu Y., Miyadera T. J. Hazard. Mater. 2005, 122, 1-6.

9. McGuire C.M., Peter D.G. Electrochim. Acta 2014, 137, 423430.

10. Nagpal V., Bokare A.D., Chikate R.C., Rode C.V., Paknikar K.M. J. Hazard. Mater. 2010, 15, 680-687.

11. Kaur B., Srivastava R., Satpatai B. Catal. Sci. Technol. 2016, 6, 1134-1145.

12. Gantzer C.J., Wackett L.P. Environ. Sci. Technol. 1991, 25, 715-717.

13. Chou P.C., Reinhard M. Environ. Sci. Technol. 1995, 29, 595-603.

14. Assaf-Anid N., Hayes K.F., Vogel T.M. Environ. Sci. Technol. 1994, 28, 246-252.

15. Semadeni M., Chiu P.C., Reinhard M. Environ. Sci. Technol. 1998, 32, 1207-1213.

16. Wen J.X., Yu B.Q., Huang T.T., Mack J., Wildervanck M., Nyokong T., Li M.Z., Zhu W.H., Liang X. J. Electroanal. Chem. 2017, 803, 111-116.

17. Liang X., Huang T.T., Li M.Z., Mack J., Wildervanck M., Nyokong T., Zhu W.H. Appl. Catal., A: General 2017, 545, 44-53.

18. Zhu W.H., Huang T.T., Li M.Z., Zheng L.M., Bao S.S., Liang X. ChemistrySelect 2017, 2, 645-649.

19. Zhu W.H., Huang T.T., Qin M.F., Li M.Z., Mack J., Liang X. J. Electroanal. Chem. 2016, 774, 58-65.

20. Li M.Z., Liang L.L., Ni C., Liang X., Zhu W.H. J. Electroanal. Chem. 2016, 766, 135-140.

21. Liang X., Li M.Z., Mack J., Lobb K., Zhu W.H. Dalton Trans. 2018, 47, 11470-11476. 